\title{
ELEANOR KinNeY TRIBUTE
}

\author{
BARRY R. FURROW*
}

Eleanor Kinney was a giant in health law scholarship, the master of Medicare and Medicaid, the critic of medical malpractice reforms, and the scholar of government action in health care. She was someone a fledging health law scholar would turn to understand why the world of health care regulation in the United States was shaped the way it was.

I would see Eleanor at health law conferences frequently in my long career in the field, particularly in the early years when the field was younger and smaller, and intimate conversations were easier to have. We shared an interest in health care quality - my focus early on was on hospitals rather than physicians, and hers was on the role of Medicare in policing both cost and quality in hospitals, and the limits of tort reform in improving patient compensation for medical errors. I want in this brief essay to discuss two related themes that Eleanor developed masterfully in her work on Medicare: first, the evolution of the program from a benefits administration payment program to today's P4P regulator; and second, her constant concerns about beneficiaries and the quality of care they receive under Medicare, including fair treatment for adverse events. My own work has looked at the limits of tort as a compensation tool and more recently on the struggles of hospitals caught in a complex world of Pay for Performance $(\mathrm{P} 4 \mathrm{P})$ reimbursement metrics combined with Artificial Intelligence (AI) tools of detection of patient injury, and my own ideas have benefitted from her excellent scholarship.

Eleanor tackled the federal health programs, Medicare and Medicaid, early in her academic career. ${ }^{1}$ She was a master of Medicare and its development - from a beneficiary payer, to a procurement agency, and finally to a regulatory powerhouse pursuing value-based purchasing. Eleanor's work on Medicare's evolution is thorough and well footnoted; I'm struck by her sheer skill in dissecting Medicare's evolution. It is fair to say that for most health law scholars, laboring in the vineyards of Medicare was dry research indeed, lost in an everchanging and confusing regulatory morass of U.S. code provisions and payment reforms. ${ }^{2}$ Eleanor's background led her to focus on federal reimbursement programs. Early in her career, she worked as a program analyst for the U.S. Department of Health and Human Services in Washington, D.C. She later was assistant general counsel of the American Hospital Association. Her early experience was bookended by her government work for Health and Human Services and her work for the American Hospital Association-regulator and regulated, an ideal path to building an academic career based on a deep

* Barry Furrow is the Professor of Law and Director of the Health Law Program, at the Kline School of Law at Drexel University in Philadelphia; he is the lead author of the health law casebook, Health Law: Cases, Materials and Problems (8th ed. 2018).

1. See Eleanor D. Kinney, Medicare Payment to Hospitals for a Return on Capital: The Influence of Federal Budget Policy on Judicial Decision-Making, 11 J. CONTEMP. L. 453 (1984).

2. See Eleanor D. Kinney, The Accidental Administrative Law of the Medicare Program, 15 Yale J. Health Pol'y, L. \& Ethics 111 (2015). 
understanding of the world of health care regulation.

In her 2015 article "The Accidental Administrative Law of the Medicare Program," she lays out this evolution toward the modern Medicare of Accountable Care Organizations, with reimbursement tied to "shared savings" and to penalty structures of quality failures such as hospital readmissions, infection rates, and patient safety indicators. ${ }^{3}$ One could design a whole health policy course around this article as the framework for more detailed readings, cases, and examples.

She describes this research area as follows: "[t]oday, the Medicare program is governed by a complex web of legislative rules, interpretive rules and manuals, policy guidance and computer programs which guide a host of decisions on issues related to the operation of the Medicare program." "From a young scholar's perspective, this is a daunting starting point in understanding a system. Fortunately, Eleanor has done the work for us. She carefully outlined the building blocks with clear graphic depictions of structure. ${ }^{5}$ And she masterfully laid out how the current contours of Medicare regulation were hardwired into Medicare's DNA. ${ }^{6}$ Her background made her one of the ideal health law academics to trace this evolution. She observed that unlike other federal benefit programs that provided health care services and items, Medicare had to act as a purchaser of covered items and services from independent vendors rather than just distributing cash. ${ }^{7}$ In her words, "Medicare eventually had to become a procurement program and finally a regulatory program. Because of the inflationary costs and charges presented by providers and suppliers for compensation, the Medicare program had to resort to rate regulation to control Medicare expenditures."

I was a young lawyer at a law firm in Boston during the early 1970s, as Medicare blossomed into a major payer of hospital expenses. I represented, among my firm's clients, Massachusetts General Hospital, and in that early era of Medicare, I handled a Medicare reimbursement hearing triggered by a Government Accounting Office audit of the hospital. The appeals process was chaotic, administered by a fiscal intermediary, with no one really understanding the alleged overcharge. I was left to represent the hospital since no senior lawyer in my firm wanted anything to do with it. This was early in the awkward evolution of Medicare as solely a payor of benefit costs, and it was already clear that Medicare had to evolve beyond a mere payor to better police errors and what would eventually become massive Medicare fraud.

The need for Medicare to change was obvious. Eleanor was a student of Medicare early in her career, as she cataloged its metamorphosis from benefits provider to benefits procurer to benefits policer to a benefit-cost mediator (and collaborator). This evolution of a benefits program to a financer of new delivery

3. Id.

4. Id. at 111 .

5. Id. at 113 .

6. Id. at 115 .

7. $I d$.

8. Id. 
models such as ACOs was driven by the vast sums of money that health care delivery required, the rapid growth of payments, and the need to protect the beneficiaries and more importantly the federal budget. ${ }^{9}$ Eleanor writes:

Throughout this transformation, and with the mindset of a benefits program, Medicare policy-makers wrestled with associated administrative law issues with a poor sense of how administrative law functions in a regulatory context. The result of their deliberations was the development of unanticipated and often unique procedures for making rules and policy, enforcing regulatory requirements and adjudicating disputes. ${ }^{10}$

Medicare has adapted, as Eleanor notes, developing a more collaborative approach to achieving regulatory goals, particularly with the growth of Accountable Care Organizations. ${ }^{11}$ These ACOs, seeking the balance of higher quality care at a lower cost, are a big jump beyond crude cost containment tools that preceded ACOs. She correctly sings the praises of ACOs as offering a better model of delivery, involving patients, based on treatment evidence, and combining providers into a much more coordinated framework. ${ }^{12}$ This could well be a Medicare success story in its evolution toward a collaborator with providers in promoting new models of care.

Let me introduce a critique of Medicare as a regulator at this point. The other prong of Medicare reimbursement may be the Mr. Hyde of Medicare's regulatory toolbox. Medicare has become excited by the use of reimbursement to punish by penalizing hospitals. The use of pay-for-performance metrics are designed to focus on measurable specific conditions like Hospital-Acquired Conditions (HACs), through the HAC Reduction Program ${ }^{13}$, and through the use of patient outcome measures, such as patient safety indicators (PSIs) to score hospitals. ${ }^{14}$

Fix the problem or take a Medicare reimbursement hit, says CMS to thousands of U.S. hospitals. ${ }^{15} \mathrm{CMS}$ brags that its non-payment policy for HACs, including MRSA and $C$. diff infections, has already saved Medicare almost $\$ 350$

9. See id. at $114,117$.
10. Id.
11. Id. at 139.
12. Id. at 135 .
13. Hospital-Acquired Condition Reduction Program (HACRP), CTRS. FOR MEDICARE \& MedicAid SERvs., https://www.cms.gov/Medicare/Medicare-Fee-for-ServicePayment/AcuteInpatientPPS/HAC-Reduction-Program.html [https://perma.cc/82Y8-3AC8].

14. Fact Sheet on Patient Safety Indicators, AgenCy HealthCARE ReSEARCH \& Quality https://www.ahrq.gov/sites/default/files/wysiwyg/professionals/systems/hospital/qitoolkit/combi ned/alb_combo_psifactsheet.pdf [https://perma.cc/RY8M-4LBV].

15. Hospital-Acquired Condition Reduction Program Fiscal Year 2020 Fact Sheet, CTRS. FOR MedicAre \& MedicAid SERvs., https://www.cms.gov/Medicare/Medicare-Fee-for-ServicePayment/AcuteInpatientPPS/Downloads/HAC-Reduction-Program-Fact-Sheet.pdf [https://perma.cc/Z75U-JXNR]. 
million each year. ${ }^{16}$ However, these figures represent money saved by Medicare but money lost to hospitals, ${ }^{17}$ which they could have spent on other areas of patient care. Here, Medicare as the policer of adverse event costs has created tools that appear to be hardening Medicare into a tougher and less flexible collaborator on patient quality metrics. Eleanor would have read the new studies of the past two to three years and raised her voice to suggest that Medicare needed to do much more work to sort out the validity of reimbursement measures used, or much staff time and hospital money would be wasted. ${ }^{18}$

These Pay-for-Performance penalty tools can be fixed, and hopefully will be, before billions in hospital income is misdirected..$^{19}$ ACOs, on the other hand, hold out the promise of successfully striking the right balance but using a less intrusive regulatory approach to a new delivery structure of which physicians are willing to be part. ${ }^{20}$

My second theme in Professor Kinney's scholarship is that of patient quality and the treatment of Medicare adverse events. The previous discussion points to Medicare's emergence as the promoter of new models of health care organizations such as ACOs and new sharp-edged reimbursement penalty tools to reduce patient adverse events. It is clear that Medicare is now obsessed not only with cost but also quality, although the quality metrics may not yet be sufficiently tested to be trusted. ${ }^{21}$ I'm more interested here in looking at Eleanor's prescient writing on a Medicare system that would provide a compensation

16. Hospital-Acquired Condition (HAC) Reduction Program, CTRS. FOR MEdiCARE \& MEDICAID SERvs., https://www.cms.gov/Medicare/Quality-Initiatives-Patient-AssessmentInstruments/Value-Based-Programs/HAC/Hospital-Acquired-Conditions [https://perma.cc/26ZH$\mathrm{UX} 4 \mathrm{G}]$.

17. See Jessica Martin, Substantial Economic Burden Attributed to Recurrent Clostridium Difficile, Infectious Disease Advisor (Feb. 21, 2019), https://www. infectiousdiseaseadvisor.com/home/topics/gi-illness/clostridioides-difficile/substantialeconomic-burden-attributed-to-recurrent-clostridium-difficile/ [https://perma.cc/23SMN37C] (explaining the money lost by hospitals for treatment of $C$. diff infections, i.e. the money lost by hospitals as a result of CMS' non-payment policy for HACs).

18. See Elizabeth A. Fehlberg, Robert J. Lucero, Michael T. Weaver, Anna M. McDaniel, A. Michelle Chandler, Phyllis A. Richey, Lorraine C. Mion, \& Ronald I. Shorr, Impact of the CMS No-Pay Policy on Hospital-Acquired Fall Prevention Related Practice Patterns, 1 INNOVATION IN AgING Art. igx036 at 1 (2017), https://www.ncbi.nlm.nih.gov/pmc/articles/PMC6002153/ pdf/igx036.pdf [https://perma.cc/JK84-SRBK]. ("The CMS no-pay policy increased utilization of fall prevention strategies despite little evidence that these measures prevent falls.”)

19. See generally Aaron Mendelson, Karli Kondo, Cheryl Damberg, Allison Low, Makalapua Motúapuaka, Michele Freeman, Maya O’Neil, Rose Relevo, \& Devan Kansagara, The Effects of Pay-for-Performance Programs on Health, Health Care Use, and Processes of Care: A Systematic Review, 166 Annals Internal Med. 341 (2017).

20. Kinney, supra note 2, at 134-35, 138.

21. See Niall Brennan, Allison Oelschlaeger, Christine Cox, and Marilyn Tavenner, Leveraging The Big-Data Revolution: CMS Is Expanding Capabilities To Spur Health System Transformation, 33 HeALth AfFs. 1195, 1196 (2014). 
scheme for patients who suffer adverse events. Her article, with William Sage, that I want to talk about is "Dances with Elephants: Administrative Resolution of Medical Injury Claims by Medicare Beneficiaries." This article offers a possible future for the new and improved Medicare as a quality promoter through the use of Medicare's Quality Improvement Organizations ("QIOs"). ${ }^{22}$

Eleanor in this article notes the limits of QIOs as quality improvement tools. They exclude quality of care problems from mediation, thereby hiding provider errors from beneficiaries. ${ }^{23}$ QIOs also take few corrective actions against providers even with valid complaints. ${ }^{24}$ They fail to share information with other regulatory bodies. ${ }^{25}$ They are little more than tort-excluding, anti-compensatory creations of the early history of Medicare. ${ }^{26}$ But they have great potential as a platform for a patient compensation process. Eleanor jumps right to the recommendation of a "radical reinvention" of Medicare's complaint review process: "give QIOs both the authority and the responsibility not only to review complaints, but also to provide beneficiaries with complete information and appropriate compensation for medical injury." ${ }^{27}$ She contends that giving Medicare an injury compensation system for beneficiaries "could have a salutary effect on the malpractice system as well as on the weak system of complaint review that Medicare currently supports." ${ }^{28}$

QIOs haven't yet evolved into a valuable federal compensation system, but Medicare evolution in its use of system reform and reimbursement penalties perhaps has opened to door to Eleanor's elegant proposal. Political pressure for a government-administered patient compensation system is currently lacking in the United States. A storm may however be brewing. First, hospitals are facing doctrinal movements in state courts to expand their exposure to liability, through corporate negligence doctrine. ${ }^{29}$ Courts have become impatient with the halo defense that nonprofit hospitals used to be able to use. ${ }^{30}$ Second, the level of adverse events in hospitals seems to be increasing, ${ }^{31}$ in spite of Medicare efforts through CMS reimbursement penalties, readmissions, and hospital-acquired conditions. Third, the consumer movement in health care, as seen in patient

22. Eleanor D. Kinney \& William M. Sage, Dances with Elephants: Administrative Resolution of Medical Injury Claims by Medicare Beneficiaries, 5 Ind. HeAlth L. ReV. 1 (2008).

23. Id. at 5 .

24. Id.

25. Id.

26. See id. at 4 .

27. Id. at 6 .

28. Id.

29. See Larson v. Wasemiller, 738 N.W.2d 300, 306-07 (Minnesota, 2007) (adopting negligent credentialing for Minnesota, the court noted that more than half of the state courts have adopted the tort. The concept also has support in Restatement (Second) Tort sections such as sections 320 and 411).

30. See Scott v. SSM Healthcare St. Louis, 70 S.W. 3d 560 (Mo. App. Ed. 2002).

31. David C. Classen et al., 'Global Trigger Tool' Shows that Adverse Events in Hospitals May Be Ten Times Greater than Previously Measured, 30 Health Aff. 581, 581 (2011). 
engagement models and drives toward transparency in hospital billing, ${ }^{32}$ is sharpening citizen awareness of system failures in the U.S. health care system. Fourth, the growth in the sheer size of baby boomers retiring into the Medicare system provides fuel for disruptive changes. ${ }^{33}$

CMS innovations in reimbursement through reimbursement and system reforms still leave patients "bare" when it comes to compensating them for infections, patient safety incidents, and other adverse events that have hurt them. For the elderly Medicare patients, who have little access to the tort system anyway because of the problems in proving substantial damages, they are truly lost. Eleanor wrote many articles on medical malpractice and tort reform. Her work on QIOs suggests a masterful solution - a federal adverse event compensation model that schedules damage payouts, works efficiently through an administrative structure and thereby creates the financial pressures to force hospitals to pay attention at the highest level to adverse event generation. ${ }^{34}$ It is a perfect pairing for reimbursement penalties.

I have learned a great deal from Professor Eleanor Kinney over my career. She was a friend, a colleague, a sharp-edged critic of government policy, and an astute observer of Medicare. She was one of the few scholars I would trust when I needed to fill in my own ignorance of Medicare and its regulatory tools. And as I have reread, or read for the first time, her remarkable corpus of work, I see a remarkable mind at work - thorough, innovation, collaborative. She will be missed.

32. See Julia James, Health Policy Brief: Patient Engagement (2013), https://www.healthaffairs.org/do/10.1377/hpb20130214.898775/full/healthpolicybrief_86.pdf [https://perma.cc/TBD5-RUVZ].

33. See c2 b solutions, Understanding Boomers, a Disruptive Force in American HEALTHCARE (2019), https://cdn2.hubspot.net/hubfs/300901/docs/Understanding_Boomers_A_ Disruptive_Force_in_American_Healthcare.pdf?t=1455206530609 [https://perma.cc/N3GE-ENLJ].

34. Kinney \& Sage, supra note 22, at 6-7. 